\title{
New Record of Indian Hill Trout Barilius bendelisis (Cypriniformes: Cyprinidae) from Kangsabati Reservoir, West Bengal, India
}

\author{
V. Kumar*, Lianthuamluaia, U.K. Sarkar, C.M. Roshith, D. Panda, K.M. Sandhya, \\ S. Kumari, P. Mishal, B.K. Naskar, Y. Ali and G. Karnatak \\ ICAR-Central Inland Fisheries Research Institute (CIFRI), Barrackpore, Kolkata-700120, India \\ *Corresponding author
}

\section{A B S T R A C T}

Keywords

Barilius bendelisis,

Cyprinidae,

Kangsabati

Reservoir, Ganga

River system.

Article Info

Accepted:

05 January 2017

Available Online:

10 February 2017
Exploration and characterization of germplasm resource is important for documentation of species. The present study reports new distribution record of Indian hill trout, Barilius bendelisis (Hamilton 1807) from Kangsabati Reservoir, West Bengal, India. Based on the past records and literature this is the first report of Barilius bendelisis a member of Cyprinidae family from the Kangsabati Reservoir, under Damodar basin, Ganga River system in West Bengal. The species is defined as a species of Barilius with dorsal profile is less convex than that of ventral; dorsal fin entirely inserted in advance of anal fin; lateral line complete with 40-42 scales and runs in the lower half of the body and predorsal scales 19; each scale with black spot and anal fin short with 8 branched rays. The paper also provides detailed diagnostic characters of the studied species.

\section{Introduction}

Barilius bendelisis was originally described by Hamilton in 1807 as Cyprinus bendilisis, based on the specimen collected from Cedawáti (Vedawati) stream, headwaters of Krishna River near Heriura, Mysore, which was later placed under the genus Barilius (Day, 1878). Subsequently, it has been reported by Hora and Mukerjee (1936), Lai and Chatterjee (1962), Singh (1964) and Grover (1970) from rivers of Doon valley, outer Himalaya, Uttarakhand, India. Barilius bendelisis, commonly known as Indian Hill Trout and Khoksa or joia (West Bengal), is an upland water fish of South East Asia, commonly distributed in Brahmaputra and hills (Kurup et al., 2004; Sahoo et al., 2009). It belongs to the family Cyprinidae and dwells in shallow, clear and cold water (Gurung et al., 2005). The fish contributes significantly to the capture fishery in several parts of the Himalayan region of Uttarakhand, where Indian major carps and exotic carps cannot be raised successfully (Mir et al., 2015). The fish is characterized by its relatively elongated compressed body, blue black bars or spots on the body and dorsal fin present behind the middle of the body. The maximum length recorded for this fish species is $22.7 \mathrm{~cm}$ (Rahman, 1989). Adults of this fish are found in streams and rivers along the base of hills 
(Talwar and Jhingran, 1991) with pebbly and rocky bottom (Menon, 1999). As per IUCN (2012) status this fish species has been categorized as of least concern (LC) but in the near future it is likely that over exploitation and habitat destruction may pose major threat to its fishery. The Kangsabati Reservoir in West Bengal, India, under Damodar basin is connected with the Ganga River system. Its icthyofaunal diversity is poorly explored till date (Kumar et al., 2017). Collections from the exploratory survey conducted under the present study from this Reservoir include an undescribed species of Barilius which is herein described as a new record.

\section{Materials and Methods}

A total of 3 number of specimens $(\mathrm{n}=3)$ of $B$. bendelisis (Image 1) were collected from Kangsabati Reservoir $\left(23^{\circ} 02^{\prime} 31.8^{\prime \prime} \mathrm{N}\right.$, $86^{\circ} 43^{\prime} 33.6^{\prime \prime E}$ ) (Figure 1) by using cast net and gill net during October 2015. Measurements were made point to point on the left side of specimens wherever possible with dial calipers to the nearest $0.1 \mathrm{~mm}$. The colour in fresh specimens was noted before fixation and preservation in $10 \%$ formalin (Kumar and Hassan 2015). Counts and measurements follow Kottelat (1990) and lateral line scale count, Kottelat (2001). Head length (HL) and anatomical measurements are expressed as proportions of standard length (SL) and subunits of head as proportions of head length (HL) (Dishma and Vishwanath 2012). Vertebral counts follow Weitzman (1962). Fin rays were counted under a stereo-zoom light microscope.

\section{Results and Discussion}

\section{Description}

Body elongated and compressed with moderately cleft mouth. One short pairs of barbels present. Dorsal profile is less convex than that of ventral. Dorsal fin higher than the length of its base; it commences nearer the base of the caudal fin than the tip of snout and does extend to over the anal fin and is inserted posterior to the ventral. Dorsal fin entirely inserted in advance of anal fin. Lateral line complete with 40-42 scales and runs in the lower half of the body and predorsal scales 19. Each scale with black spot and anal fin short with 8 branched rays.

D ii 7; P 13-14; V 9; A ii 8; C 18

The morphometric details of the specimen i.e., total length, standard length, body depth, length of the snout, fork length, body depth, post orbital length of head, diameter of eye, inter orbital distance, inter nostril distance, head length, head depth, head width etc. are given in table 1 . In all the biometric characters, body proportions and colour pattern, the specimen agrees with the description given by Hamilton (1807); Talwar and Jhingran (1991); Rahman (1989); Jayaram (2010) and Shafi and Quaddus (2001).

\section{Colour}

Body is silvery with greyish black dark bands descending towards the lateral line and becoming indistinct in older specimens. Fins whitish tinged with orange. Margin of dorsal and caudal are greyish. Colour pattern shows that there are blotches descending to lateral line and the fins are yellow tinted with black edges. They are brightly coloured, with golden yellowish operculum, greenish snout, orange coloured lower jaw, small tubercles on both jaws, orange fringes on the paired and anal fins, and with yellowish but blackmargined caudal fin. Each scale in the adult is with a black spot at its base, and each forming the lateral line.

\section{Habitat and ecology}

The Kangsabati Reservoir is a tributary of Damodar River and which is a part of Ganga 
River system. The sampling site is located around $50 \mathrm{~km}$ away from the Bankura district $\left(23^{\circ} 02^{\prime} 31.8^{\prime \prime} \mathrm{N}, \quad 86^{\circ} 43^{\prime} 33.6^{\prime \prime} \mathrm{E}\right)$ of West Bengal. The average physico-chemical properties of the sampling site was $\mathrm{pH}-7.87$, depth- $2.83 \mathrm{~m}$, transparency- $127.7 \mathrm{~cm}$, water temperature- $23{ }^{\circ} \mathrm{C}$, dissolved oxygen- 6.8 and specific conductivity- $158.4 \mu \mathrm{s} / \mathrm{cm}$. The downstream is highly disturbed due to anthropogenic activities e.g. boating, bathing, construction activities etc. This species was not observed in the downstream of the river. The species is found to inhabit streams and rivers along the base of hills with pebbly and sandy bottom. Adults occur in streams and rivers along the base of hills with pebbly and rocky bottom.

\section{Distribution}

The published information on the distribution of $B$. bendelisis has been presented in table 2 . Occurence of this species have also been reported from hill stream and rivers with rocky bottom (Rahman, 2005; IUCN Bangladesh, 2000). This species is an important commercial hill stream fish in Jammu and areas of eastern Himalaya (Talwar and Jhingran, 1991). This is a new distribution record from the Reservoir.

Table.1 Morphometric characters for Barilius bendelisis

\begin{tabular}{|l|l|l|l|l|}
\hline Morphometric data & Specimen 1 & Specimen 2 & Specimen 3 & Mean \\
\hline Total length (mm) & 65.4 & 120.9 & 96.2 & 94.17 \\
\hline Standard Length (mm) & 52.6 & 97.5 & 78.1 & 76.07 \\
\hline In \% of standard length & & & & \\
\hline Body Depth & 26.05 & 25.74 & 27.14 & 26.31 \\
\hline Head Length & 23.00 & 22.26 & 22.54 & 22.60 \\
\hline Caudal peduncle length & 16.73 & 16.21 & 17.80 & 16.91 \\
\hline Caudal Peduncle depth & 9.13 & 9.85 & 9.99 & 9.65 \\
\hline Upper Jaw length & 10.46 & 15.08 & 16.90 & 14.14 \\
\hline Lower Jaw length & 9.70 & 12.72 & 13.44 & 11.95 \\
\hline Dorsal Fin length & 18.25 & 18.26 & 17.41 & 17.97 \\
\hline Pectoral Fin length & 18.06 & 18.56 & 18.44 & 18.35 \\
\hline Pelvic Fin length & 13.88 & 13.73 & 13.70 & 13.77 \\
\hline Anal Fin length & 16.16 & 13.44 & 13.83 & 14.47 \\
\hline Caudal Fin length & 22.62 & 22.36 & 23.69 & 22.89 \\
\hline Dorsal Fin Base length & 10.65 & 11.59 & 12.16 & 11.47 \\
\hline Anal Fin base length & 10.46 & 12.72 & 12.04 & 11.74 \\
\hline Pre Dorsal Length & 48.29 & 58.77 & 55.31 & 54.12 \\
\hline Pre Pectoral Length & 25.86 & 26.46 & 26.63 & 26.32 \\
\hline Pre Pelvic Length & 49.81 & 52.82 & 52.88 & 51.84 \\
\hline Pre Anal Length & 65.59 & 73.64 & 72.22 & 70.48 \\
\hline In \% of head length & & & & \\
\hline Eye diameter & 26.45 & 18.89 & 22.73 & 22.69 \\
\hline Head depth & 64.46 & 80.64 & 78.98 & 74.69 \\
\hline Head Width & 40.50 & 46.54 & 42.04 & 43.03 \\
\hline
\end{tabular}


Table.2 Published information on distribution of Barilius bendelisis

\begin{tabular}{|l|l|l|}
\hline S. No. & Occurrence & Source \\
\hline 1 & $\begin{array}{l}\text { Cedawáti (Vedawati) stream, headwaters } \\
\text { of Krishna River near Heriura, Mysore }\end{array}$ & Hamilton (1807) \\
\hline 2 & $\begin{array}{l}\text { Maungmagan, Tavoy District, Lower } \\
\text { Burma }\end{array}$ & Hora and Mukerjee (1936) \\
\hline 3 & Doon valley, Uttar Pradesh & $\begin{array}{l}\text { Lai and Chatterjee (1962), Singh } \\
(1964)\end{array}$ \\
\hline 4 & Song River in Dun Valley, Uttar Pradesh & Grover (1970) \\
\hline 5 & River Dikrong, Arunachal Pradesh & Sahoo et al. (2009) \\
\hline 6 & River Buroi, Arunachal Pradesh & Hazarika et al. $(2011)$ \\
\hline 7 & $\begin{array}{l}\text { Tributaries of Ramganga river, Western } \\
\text { Himalaya }\end{array}$ & Atkore et al. (2011) \\
\hline 8 & River Kosi, near Almora, Uttarakhand & Barat et al. (2012) \\
\hline 9 & Ken River basin, Madhya Pradesh & Johnson et al. (2012) \\
\hline 10 & $\begin{array}{l}\text { Upper zone (Uttarakhand), Northern } \\
\text { Himalayan, river Ganga }\end{array}$ & Sarkar et al (2012) \\
\hline 11 & $\begin{array}{l}\text { Spring-fed hill-stream Relli, Darjeeling } \\
\text { Himalaya, West Bengal }\end{array}$ & Acharjee and Barat (2014) \\
\hline 12 & Garhwal Himalaya, India & Mir et al. (2015) \\
\hline 13 & $\begin{array}{l}\text { River Gaula, Kosi, Alaknanda and } \\
\text { Mandakini, Central Indian Himalaya }\end{array}$ & Mir et al. (2015) \\
\hline 14 & Bhavanisagar Reservoir, Tamil Nadu & Raja et al. (2015) \\
\hline
\end{tabular}

Fig.1 Map showing locality of Barilius bendelisis indicated as a star

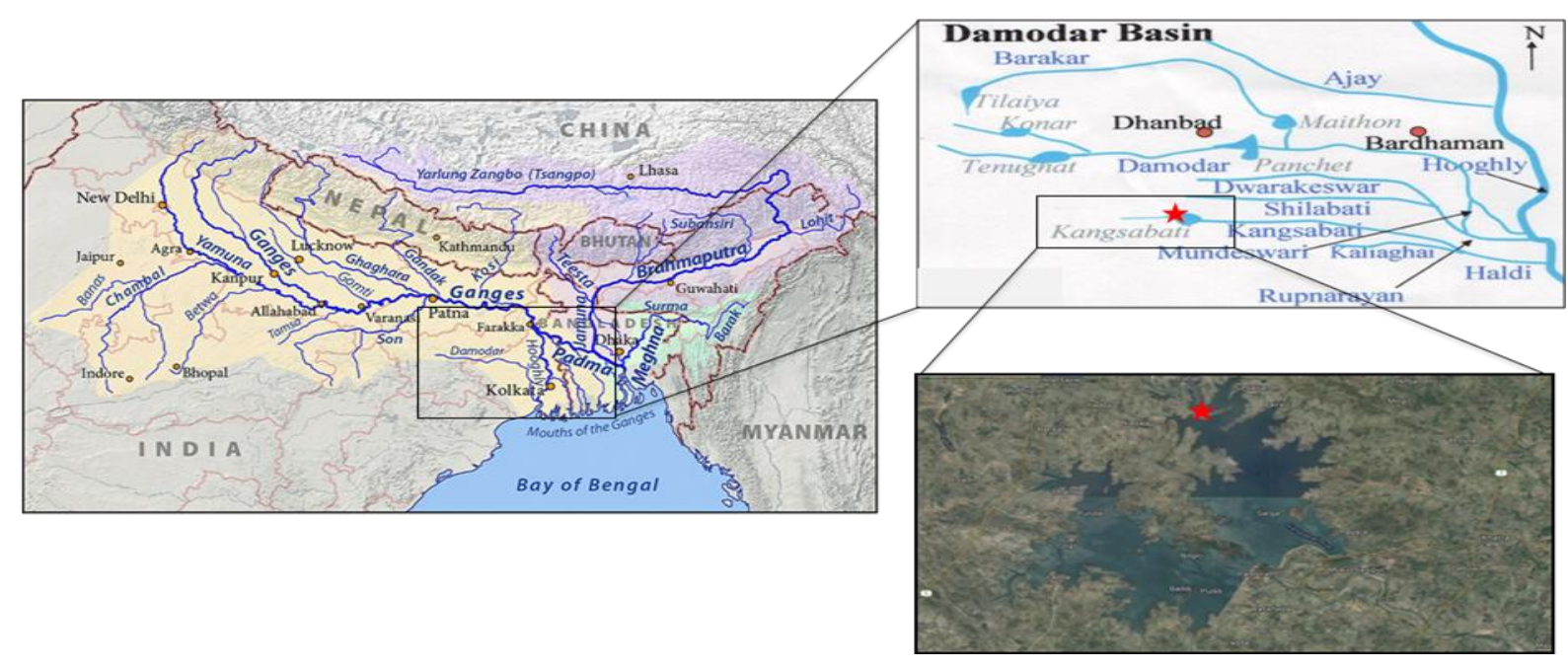


Image.1 Barilius bendelisis (A) Side view, i- fresh specimen, ii- formalin preserved specimen (B) Ventral view
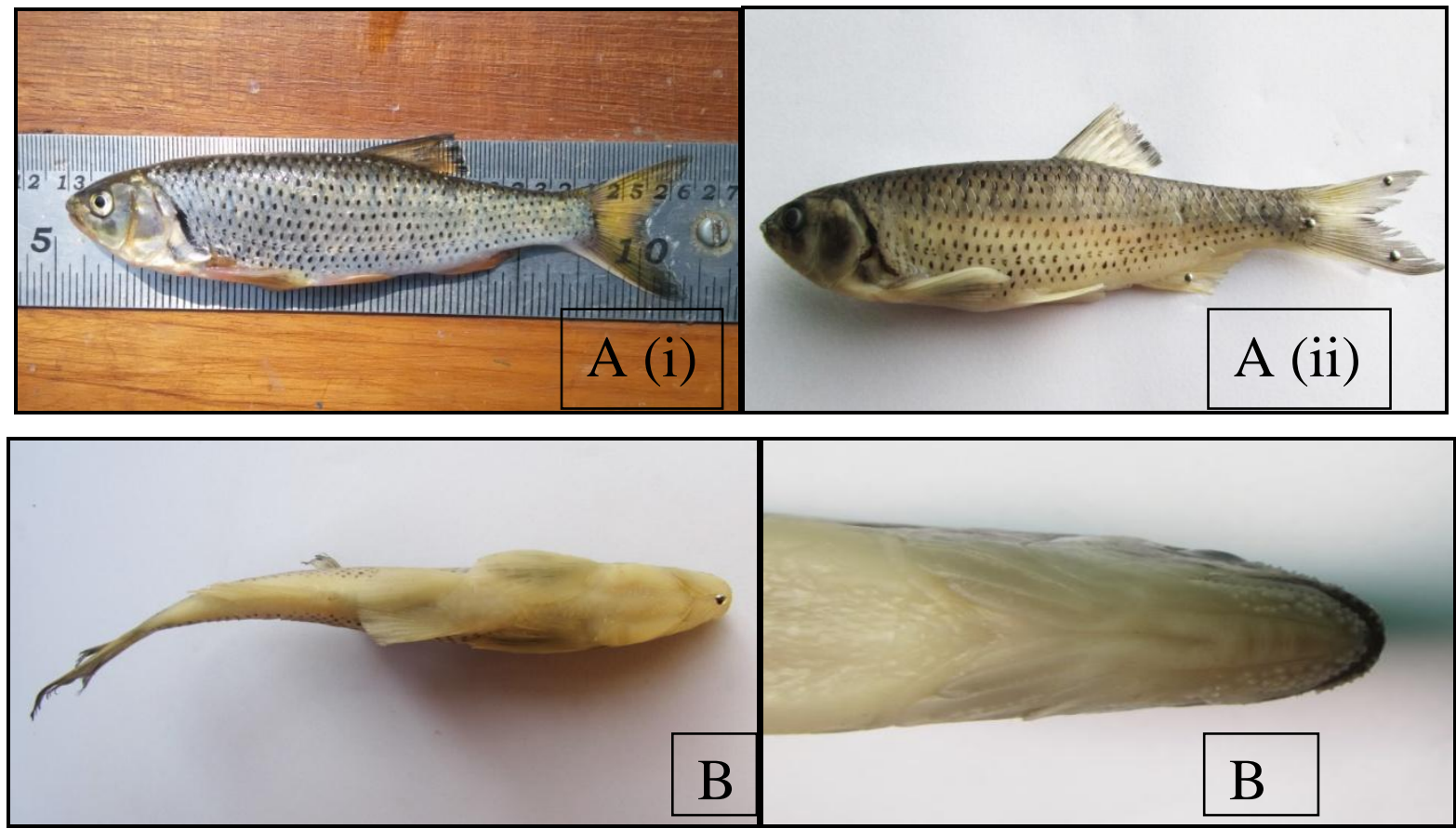

In the present study, B. bendelisis of the genus Barilius from Kangsabati Reservoir, West Bengal, India, have been examined in detail and described from this region for the first time. The genus Barilius is represented by 34 species reported from Asian region and some of the commonly available species are namely $B$. ardens, B. bakeri, B. bernatziki, $B$. bonarensis, B. canarensis etc.

Talwar and Jhingran (1991) and Jayaram (2010) reported coloration of the body, presence of barbels, anal fin shape with branched rays, number of scales in lateral line with black spot in $B$. bendelisis. The morphometric and meristic characteristics of the specimens collected have been found to be similar when compared with already reported specimens of Barilius bendelisis. The diagnostic features (Table l) also distinctly show that the species under report, $B$. bendelisis could be readily separated from all the reported species as well as the synonymies of the Genus Barilius (Day, 1878; Talwar and Jhingran, 1991; Menon, 1999; Jayaram, 1999; Vishwanath and Manoj Kumar, 2002). B. bendelisis was one of the common species caught in the Kangsabati Reservoir during the monsoon. It is esteemed in the region for its taste and highly priced. The fish migrates upstream from April to July and return from August to November. In other seasons, it was not present, as reported by fisherman.

The new record of $B$. bendelisis from Kangsabati Reservoir, West Bengal, India, under Damodar basin, Ganga River system has thrown a new light on the distribution of Indian hill trout in the lower stretches unlike its restricted distribution to the upper stretches of Himalayan Rivers as reported earlier. However, further studies are needed to determine the habitat preference, feeding habit and reproductive behaviour of the species so that any variability of the reported species could be further observed, if any. 


\section{Acknowledgement}

Authors are thankful to Director ICARCentral Inland Fisheries Research Institute (CIFRI) and other technical and supporting staff for the Financial and technical support.

\section{References}

Acharjee, M.L. and Barat, S., 2014. Seasonal dynamics of ichthyodiversity in a hill stream of the Darjeeling Himalaya, West Bengal, India. J. Threatened Taxa, 6(14): 6635-6648.

Atkore, V.M., Sivakumar, K. and Johnsingh, A.J.T. 2011. Patterns of diversity and conservation status of freshwater fishes in the tributaries of River Ramganga in the Shiwaliks of the Western Himalaya. Curr. Sci., 100(5): 731-736.

Barat, A., Ali, S., Khandelwal, S. and Sahoo, P.K. 2012. Genetic characterization of two coldwater fishes from Kumaun Hills, Uttarakhand. Caryologia, 65(4): 311-315.

Day, F. 1878. The Fishes of India; Being a Natural History of the Fishes Known to Inhabit the Seas and Freshwaters of India, Burma and Ceylon. William Dawson\& Sons Ltd., London, xx+778pp, 196pls.

Dishma, M. and Vishwanath, W. 2012. Barilius profundus, a new cyprinid fish (Teleostei: Cyprinidae) from the Koladyne basin, India. J. Threatened Taxa, 4(2), pp.2363-2369.

Grover, S.P. 1970. On collection of fishes of the Song River in Dun Valley, Uttar Pradesh. J. Sci. Res. India, 2: 115-118.

Gurung, T.B., Wagle, S.K., Bista, J.D., Joshi, P.L., Batajoo, R., Adhikari, P. \& Rai, A. K. 2005. Participatory fisheries management for livelihood improvement of fishers in Phewa Lake, Pokhara, Nepal. Himalayan J. Sci., 3(5): 47-52.

Hamilton, F. 1807. A journey from Madras through the countries of Mysore, Canara, and Malabar. T. Cadell and W. Davies, London: iiv + 1-479, 345, pl. 32 .

Hazarika, A., Borah, U., Bordoloi, L. 2011. Studies on morphometric measurements and meristic counts of hill trout (Barilius bendelisis, Hamilton) from the river Buroi at the boundary areas of Assam and Arunachal
Pradesh, India. Indian J. Fundamental and Appl. Life Sci., 1(3): 194-198.

Hora, S.L. and D.D. Mukerji. 1936. Notes on the fishes in the Indian Museum. XXVII.--On two collections of fish from Maungmagan, Tavoy District, Lower Burma. Records of the Indian Museum (Calcutta) v. 38 (pt 1): 15-39, Pls. 1-2.

IUCN. 2012. Red List of Threatened Species, vers. 2012.1.

IUCN Bangladesh. 2000. Red List of Threatened Animals of Bangladesh. IUCN- The World Conservation Union, Dhaka, pp. 1-54.

Jayaram, K.C. 1999. The freshwater fishes of the Indian region. Delhi. Narendra Publishing House. $551 \mathrm{p}$.

Jayaram, K.C. 2010. The Freshwater Fishes of the Indian Region. Second Edition. Narendra Publishing House, Delhi, 616pp.

Johnson, J.A., Parmar, R., Ramesh, K., Sen, S. and Murthy, R.S. 2012. Fish diversity and assemblage structure in Ken River of Panna landscape, central India. J. Threatened Taxa, 4(13): 3161-3172.

Kottelat, M. 1990. Indochinese Nemacheilines, A Revision of Nemacheiline Loaches (Pisces: Cypriniformes) of Thailand, Burma, Laos, Cambodia and southern Vietnam. Verlag, Dr. Friedrich Pfiel, Munchen, 262pp.

Kottelat, M. 2001. Fishes of Laos. Wildlife Heritage Trust, Colombo, 198pp.

Kumar, V. and Hassan, M.A. 2015. Methods and procedures of sampling, preservation and identification for fish taxonomy studies. World J. Fish and Marine Sci., 7(2): 105-108.

Kumar, V., Lianthuamluaia, Sarkar, U.K., Roshith, C.M., Panda, D., Sandhya, K.M., Kumari, S., Mishal, P., Roychowdhury, A. and Karnatak, G. 2017. New record of Chagunius chagunio (Cypriniformes: Cyprinidae) from Kangsabati Reservoir, West Bengal, India. Int. J. Curr. Microbiol. Appl. Sci., 6(2).

Kurup, B.M., Radhakrishnan, K.V. \& Manojkumar, T.G. 2004. Biodiversity status of fishes inhabiting rivers of Kerala (South India) with special refernce to endemism, threats and conservation measures. In. Welcomme, R. L. \& Peter, T. (Eds.). Proceeding of the second international symposium on the management of large rivers 
for fisheries. Vol. 2, 11-14 February, 2003, Phnom Penh, Kingdom of Cambodia.

Lai, M.B. and P. Chatterjee. 1962. Survey of Eastern Doon fishes with certain notes on their biology. J. Zool. Soc India, 14(2): 203243.

Menon, A.G.K. 1999. Check list - fresh water fishes of India. Zool. Survey of India, 175: 366.

Mir, J.I., Patiyal, R.S. and Sharma, N.K. 2015. Analysis of length-weight relationship of sympatric hill stream teleosts Barilius bendelisis (Hamilton, 1807) and Barilius vagra (Hamilton, 1822) from Garhwal Himalaya, India. J. Appl. Ichthyol., 31(4): 771-772.

Mir, J.I., Saxena, N., Patiyal, R.S. and Sahoo, P.K., 2015. Phenotypic differentiation of Barilius bendelisis (Cypriniformes: Cyprinidae) in four rivers from Central Indian Himalaya. Revista de Biología Tropical, 63(1): 165-173.

Rahman, A.K.A. Freshwater Fishes of Bangladesh. 2nd ed. Zoological Society of Bangladesh, Dhaka, Bangladesh. 2005.

Rahman, A.K.A. 1989. Freshwater fishes of Bangladesh. Zool. Society of Bangladesh, 364.

Raja, M., Ramkumar, R., Kavitha, M. and Perumal, P. 2015. Distribution pattern, threatened status and conservation measures of fishes with relation to water quality and habitat characteristics of Bhavanisagar Reservoir, Tamil Nadu. Int. J. Fisheries and Aquatic Studies, 2(6): 11-18.

Sahoo, P.K., Saikia, S.K., \& Das, D.N. 2009.
Natural food resources and niche breadth of Barilius bendelisis (Hamilton) (Pisces, Cyprinidae) in river Dikrong, an upland riverine ecosystem in India. Pan-American $J$. Aquatic Sci., 4(1), 12-16.

Sarkar, U.K., Pathak, A.K., Sinha, R.K., Sivakumar, K., Pandian, A.K., Pandey, A., Dubey, V.K. and Lakra, W.S. 2012. Freshwater fish biodiversity in the River Ganga (India): changing pattern, threats and conservation perspectives. Reviews in Fish Biol. Fisheries, 22(1): 251-272.

Shafi, M., Quddus, M.A.A. 2001. Bangladesher Matsho Sampad (Fisheries of Bangladesh) (in Bengali), Kabir publication. Dhaka, Bangladesh, 153-154.

Singh, P.P. 1964. Fishes of the Doon Valley. Ichthyologica, 3(1-2): 86-92.

Talwar, P.K. and Jhingran, A.G. 1991. Inland fishes of India and adjacent countries. Vol. 1. Balkema AA, Rotterdam.

The Fishes of India. Being a Natural History of the Fishes Known to Inhabit the Seas and Fresh Waters of India, Burma, and Ceylon. Quaritsch, London, i-xx, 553-778, pls. 139195.

Vishwanath and Manoj Kumar, B. 2002. A New Bariliine Cyprinid Fish of the Genus Barilius Hamilton from Manipur, India. J. Bombay Natural History Society, 99(i): 86-89.

Weitzman, S.H. 1962. The osteology of Brycon meeki, a generalized Characid fish, with an osteological definition of the family. Standford Ichthyol. Bull., 8(1): 1-77.

\section{How to cite this article:}

Kumar, V., Lianthuamluaia, U.K. Sarkar, C.M. Roshith, D. Panda, K.M. Sandhya, S. Kumari, P. Mishal, A.R. Chowdhury and Karnatak, G. 2017. New Record of Indian Hill Trout Barilius bendelisis (Cypriniformes: Cyprinidae) from Kangsabati Reservoir, West Bengal, India. Int.J.Curr.Microbiol.App.Sci. 6(2): 104-110. doi: http://dx.doi.org/10.20546/ijcmas.2017.602.015 